\title{
The Roles of Muhtasib in Islamic Medieval Urban Management
}

\author{
Tengku Nurul Saadah Tengku Zawawi, Amal Hayati Ishak, Mohd Dani Muhamad
}

\author{
Academy of Contemporary Islamic Studies, \\ Universiti Teknologi MARA (UiTM), Shah Alam 40450, Malaysia
}

tgnurulsaadah@yahoo.com, amalhayati@uitm.edu.my, mdani393@uitm.edu.my

Tel of 1st Author: +60166186321

\begin{abstract}
The medieval Islamic cities were described to be systematically managed by the institution of hisba, henceforward, inspiring modern Muslims to revive the Islamic paradigm of urban management. Nevertheless, not much is being discussed on the role of muhtasib as an urban regulator. Furthermore, it has been wrongly understood only as a market inspector. Thus, employing the content analysis approach, this article examines the roles of muhtasib in urban management, based on selected manuals of muhtasib, written during the medieval times. Interestingly, the findings indicate a series of Islamic principles on urban management that match modern urban management, albeit the difference of time.
\end{abstract}

Keywords: Hisba; Urban Management; Medieval Islam; Islamic Civilization

eISSN: 2398-4287@ 2021. The Authors. Published for AMER ABRA cE-Bs by e-International Publishing House, Ltd., UK. This is an open access article under the CC BY NC-ND license (http://creativecommons.org/licenses/by-nc-nd/4.0/). Peer-review under responsibility of AMER (Association of Malaysian Environment-Behaviour Researchers), ABRA (Association of Behavioural Researchers on Asians/Africans/Arabians) and CE-Bs (Centre for Environment-Behaviour Studies), Faculty of Architecture, Planning \& Surveying, Universiti Teknologi MARA, Malaysia.

DOI: https://doi.org/10.21834/ebpj.v6iSI5.2947

\subsection{Introduction}

An urban populates a high-density population and various buildings, including homes, commercial premises, educational centers, hospitals, and other vital facilities (Rutledge et al., 2011). Thus, good urban management is critical in improving the quality of life and managing and solving various adverse effects resulting from poor planning and maintenance of facilities as well as unethical behaviors of the citizens (Bhadur, 2017).

For that reason, urban management is a crucial and developing sector, particularly due to the cities' contribution as the catalyst in political, administrative, economic, and social activities (Abdilla bin Khairol, 2013; Lagiman, 2015). Epistemologically, urban management is an ever-changing sector, stemming from the past two to three decades to cope with the ever-changing growth and development of cities (Bačlija, 2013). As a part of the public sector, urban administrators are obliged to comply with the principles of good governance and relevant local legislation.

Looking into the remarkable success stories of cities during previous Islamic civilization (Manzano, 2015), there lies a unique paradigm of urban management practice, aimed at nurturing and sustaining civility, prosperity, unity, and happiness among multi-racial and multi-cultural people for more than 1000 years (Abbasi et al., 2010). The unique Islamic paradigm of urban management has inspired modern Muslim leaders in their respective states to adopt Islamic urban management.

For instance, the state of Kelantan in Malaysia had named its capital as the Islamic city of Kota Bharu in 2005 (Saad \& Radzi, 2015). In 2013, the state of Selangor aimed to instill Islamic characters to its capital, Shah Alam (Selangorkini.my, 2013). In a recent development, Bandar Seri Begawan of Brunei has been acknowledged as Asian's 2019 Capital of Islamic Culture by the Islamic Educational, Scientific and Cultural Organization (ISESCO) and the Federation of the Universities of the Islamic World (FUIW)

eISSN: 2398-4287C 2021. The Authors. Published for AMER ABRA cE-Bs by e-International Publishing House, Ltd., UK. This is an open access article under the CC BYNC-ND license (http://creativecommons.org/licenses/by-nc-nd/4.0/). Peer-review under responsibility of AMER (Association of Malaysian Environment-Behaviour Researchers), ABRA (Association of Behavioural Researchers on Asians/Africans/Arabians) and cE-Bs (Centre for Environment-Behaviour Studies), Faculty of Architecture, Planning \& Surveying, Universiti Teknologi MARA, Malaysia. 
(www.isesco.org). Yet, these cities apply modern urban management via local council or municipal. In contrast, urban management of previous Islamic civilization vested under the jurisdiction of muhtasib, who were directly appointed by the sultan or ruler of the country.

Nevertheless, the job description of muhtasib in urban management sector has been marginally discussed, as muhtasib mainly been largely known as 'market inspector' who supervises and monitors the conformance of market rules and regulation, that's because the supervision of trade practically outweighed other sectors (Sabri Orman, 2017). Indeed, several scholars; Buckley, (2000); Moukheiber, (2019); Saraçoğlu, (2015) confine the definition of muhtasib as a market inspector.

\subsection{Literature Review}

During the medieval Islamic civilization, Hisba institution is responsible for maintaining law and order within cities. Al-Mawardi, (d. 1058 AD), in his great treatise al-Ahkam al-Sultaniyyah, defines Hisba as a duty to enjoin good and forbid evil, when both are ignored. The obligation to enjoin good and forbid evil lies under the responsibility of muhtasib, as the official of Hisba institution (Musa, 2016).

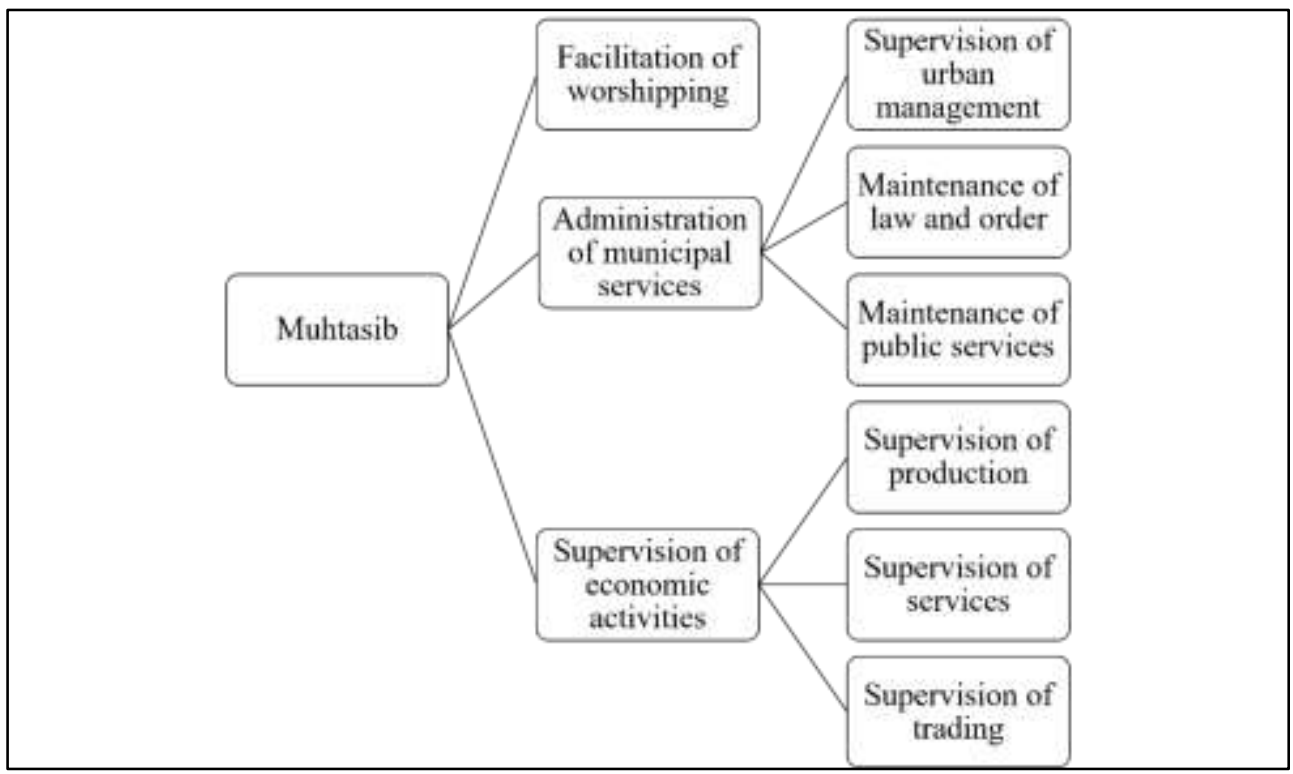

Fig. 1: The supervision of muhtasib

(source: Sabri Orman, 2017)

The duty of muhtasib was started by Prophet Muhammad with market supervision. The practice was then continued by the Prophet's companions until the official establishment of the Hisba institution during Umar's caliphate (Syarqawi, 2018). Over time, the jurisdiction of Hisba was wider expanded, including into urban management, in place of governors and qadi (judges) who previously responsible in this regard (Al-Andalusi, d. 901 AD). Moreover, Muhamad, (2018) affirms that hisba is the only organization responsible for various town services in Islamic civilization. The muhtasib was attentive to the entire realm of urban unity, both material and spiritual: religious rituals, public morality, public hygiene, security, education, welfare, as well as commerce and industry. However, muhtasib only supervises the local civil affairs within his designated provision area with limited authority in the execution of punishment. Nevertheless, the occurrence of conflicts or arguments within the locality needs to be handed over to the qadi Al-Mawardi, (d. 1058 AD).

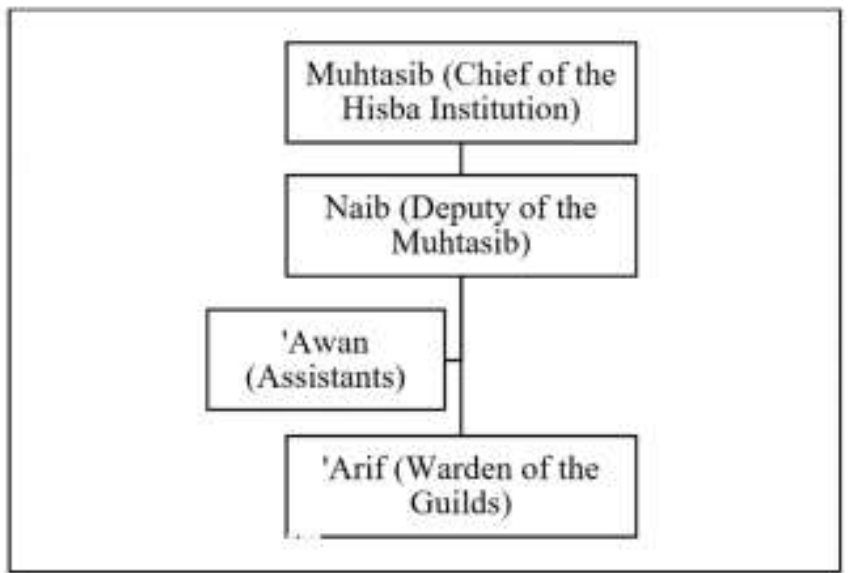

Fig. 2: Organizational structure of the institution of hisba (source: Abdullah, 2000) 
Generally, muhtasib and his assistants are responsible for guiding Muslims behavior from any divergence and not limited to market supervision (Muhamad, 2018). As illustrated in Figure 1, muhtasib supervise and monitor various sectors which covered a wide array of jurisdictions, including facilitation of worshipping, management of urban services, and supervision of trade, crafts as well as services (Sabri Orman, 2017). Each major city has only one muhtasib, as the head of the Hisba institution. They are generally known according to their respective locality of jurisdiction, such as the muhtasib of Cairo or Fustat (Stilt, 2012). Initially, muhtasib only worked alone; later, as his duties grew, the muhtasib began to appoint assistants gradually, as illustrated below in Figure 2.

Figure 2 shows that the muhtasib is assisted by a deputy known as naib, who is appointed based on similar qualifications with the muhtasib. Due to the vast job scope of muhtasib, a helper known as a'wan is appointed to assist muhtasib based on the muhtasib's orders. As compared to merely one position of muhtasib per city, the position of a'wan can reach more than ten at one time. During the Abbasid dynasty, they received a high salary amounting to around 430 dinars (Abdullah, 2000).

Beside naib and a'wan, an 'arif is also appointed to assist muhtasib. However, despite being an assistant, he acts as an advisor and mediator between Hisba institution and various sectors of guilds, such as guilds of merchant and artisan (Stilt, 2012). The 'arif is an expert in his particular industry and will disclose fraudulent tactics used in their respective industries (Al-Shayzari, d. 1193 AD). Hence, 'arif is knowledgable about the relevant rules and regulations of the industry and capable of law enforcement. Therefore, the number of 'arif also depends on the number of guilds (Abdullah, 2000; Al-Shayzari, d. 1193 AD).

\subsection{Methodology}

This study adopts a qualitative approach and applies content analysis on selected manuals of Muhtasib, as the official in the institution of hisba. Most of the manuals are composed by the muhtasib themselves as the guiding principles in performing their duties.

These manuals are written between $750 \mathrm{AD}$ until the end of 15th AD, which according to Saliba, (1994), manifests the golden period of Islamic civilization. It also was narratively written with an emphasis on essential issues of the time (Al-Andalusi, d. $901 \mathrm{AD}$ ), and excluded elements that had been previously mentioned by other manuals (Al-Shayzari, d. 1193 AD). Table 1 elucidates brief information on the manuals.

Table 1: List of Manuals of the Muhtasib

\begin{tabular}{|c|c|c|c|c|}
\hline No & Title & Author & Author's Position & $\begin{array}{r}\text { Locality of } \\
\text { Subject } \\
\end{array}$ \\
\hline 1 & Ahkam al-Suq & Umar ibn Yahya (Al-Andalusi, d. 901 AD). & Muhtasib & Kairouan, Tunisia \\
\hline 2 & Risala fi al-Hisba wa al-Muhtasib & Ahmad ibn Abd Al-Rauf, (d. $\left.8^{\text {th }} \mathrm{AD}\right)$ & Non-muhtasib & $\begin{array}{l}\text { Cordoba, } \\
\text { Andalusia }\end{array}$ \\
\hline 3 & Al-Isyarah ila Mahasin al-Tijarah & $\begin{array}{l}\text { Jaafar ibn al-Fadh ibn al-Furat al-Dimasyqi, (d. } 1001 \\
\text { AD) }\end{array}$ & Vizier & $\begin{array}{l}\text { Cairo, } \\
\text { Egypt }\end{array}$ \\
\hline 4 & & $\begin{array}{l}\text { Ali ibn Muhammad ibn Habib al-Basri al-Mawardi, (d. } \\
1058 \text { AD) }\end{array}$ & $\begin{array}{l}\text { Chief judge/ } \\
\text { diplomat }\end{array}$ & $\begin{array}{r}\text { Baghdad, } \\
\text { Iraq }\end{array}$ \\
\hline 5 & Risala fi al-Qada wa al-Hisba & Ibn Abdun Al-Ishbili, (d. early $12^{\text {th }} A D$ ) & Muhtasib & Seville, Andalusia \\
\hline 6 & $\begin{array}{l}\text { Risala fi Adab al-Hisba wa al- } \\
\text { Muhtasib }\end{array}$ & $\begin{array}{l}\text { Muhammad ibn Abi Muhammad Al-Saqati al-Malaqi, (d. } \\
12^{\text {th }} \mathrm{AD} \text { ) }\end{array}$ & Muhtasib & $\begin{array}{r}\text { Malaga, } \\
\text { Andalusia }\end{array}$ \\
\hline 7 & Risala fi al-Hisba & Umar ibn Utsman Al-Jarsifi, (d. 14th AD) & Muhtasib & $\begin{array}{r}\text { Fez, } \\
\text { Maghribi }\end{array}$ \\
\hline 8 & $\begin{array}{l}\text { Bughyat al-Irbah fi Ma'rifat Ahkam al- } \\
\text { Hisba }\end{array}$ & $\begin{array}{l}\text { Abd al-Rahman ibn Ali al-Syaibani, known as ibn Al- } \\
\text { Dibaie, (d. } 1537 \text { AD) }\end{array}$ & Muhaddith & $\begin{array}{l}\text { Zabid, } \\
\text { Yemen }\end{array}$ \\
\hline
\end{tabular}

\subsection{Findings}

\subsection{Urban Planning}

Muhtasib regulates specific land status, including special land status for the sultan, reserved area for flora and fauna, and riverside land for the public. Muhtasib must also allocate special reserved land for pasturing, as recorded by Al-Mawardi, (d. 1058 AD), based on a tradition of Prophet Muhammad saying, "Three things cannot be denied to anyone: water, pasture, and fire." (Ibn Majah, No: 2567). Therefore, According to lbn Abdun, (d. early 12th AD), reserved land for the sultan and flora and fauna could not be transacted except under particular conditions. Muhtasib also encourages land revitalization and highly concerns with the function and maintenance of tsaghr (defensive fortresses).

The land is generally divided into urban and rural (outskirts of the city) areas. The urban areas inside the city fortresses are then further subdivided into several zones for the palace, residential, commercial, and city center. Meanwhile, land on the outskirts is divided into industrial, agricultural, warehouses, waste, and cemetery zones. There is also an arrangement for residential zone based on race or religion to preserve the public's well-being.

Besides, shops and markets in the commercial zone are arranged based on the type of goods or business such as the street for food, herbs, wet products, perfume, and so on. Ibn Abdul Al-Rauf, (d. 8th AD), elaborates that; a food store must be kept away from carpentry and filthy shops such as raw meat store; proper separation of Muslims and non-Muslims slaughterhouse; placement of timber and stone factories in the outskirts including its purchasing transaction, and; placement of warehouses strategically in the outskirts but nearby 
ports to facilitate storage of goods. Along with the arrangement, a special place for muhtasib called dakka (means platform or stand) was placed inside or nearby the market to facilitate frequent inspection and monitoring. Al-Shayzari, (d. 1193 AD) recommends the placement of shops that required more observation from muhtasib must be located near to dakka (muhtasib's stand) such as foodprocessing premises.

Muhtasib also oversees the proper utilization of buildings and areas. For instance, Al-Saqati, (d. 12th AD) reports that the muhtasib of Baghdad prohibited the qadi from holding a judicial event in a mosque. Although such a thing had been done by the Messenger of Allah (may peace be upon him), the muhtasib found that some women were present with their babies and polluted the mosque with impurities. Therefore, he said, "Doing this event at your house is better." On the contrary, the Prophet once commanded Saidina Umar to depart to Iraq to burn Abu Musa al-Asyari's house due to public complaints on the difficulty of coming to his home for the judicial event.

\subsection{Conservation of the environment and biodiversity}

Ibn al-Rami (1999) highlights Islam's concern on the issue of air pollution from smoke as dictated in the Quran, "Then watch for the Day when the sky will bring a visible smoke. Covering the people, this is a painful torment." (44:10-11). Based on the premise, muhtasib orders the smoke-producing industry such as hammam (Turkish bath) and tannur (traditional oven) to apply for permission prior to operation to protect the neighborhood's well-being. The manuals also instruct for the preservation of rivers and water storage, based on analogical deduction from a hadith which prohibit urination in stagnant water (Sahih Muslim, no: 227). Therefore, muhtasib prohibits any construction along the riverbank and must demolish any impermissible building. Besides, the manual encourages new river excavation and building barriers to contain rivers to form a reservoir and prevent drought during summer. It also allows for the closure of waterways to meet human and animal needs, while plants are on third priority. The manual prohibits any ill-treatment of animals, such as; imposing a load that exceeds the capacity of an animal for a long time. Muhtasib as well must allocate a reserved land for animal grazing, which indicates the existence of proper pasture management.

Ibn al-Rami, (1999) also emphasize landscaping by encouraging tree-planting and other greening activities. Such activities are described as the basis of a place's prosperity, while trees are attributed as a source of life and elements of environmental beauty. Moreover, cutting down trees without justifiable reasons is a form of defiance in religion.

In a similar vein, Al-Andalusi, (d. $901 \mathrm{AD}$ ) encourages the muhtasib to concern on landscaping, which has been marginally emphasized in other manuals. Even, Musa, (2016) recorded that muhtasib in the Mamluk period was adamant about the building's exterior and asked the people to paint it in white, and decorate it with lights.

\subsection{Infrastructure and building}

Muhtasib is responsible in providing road, for instance, during the medieval mamluk, the muhtasib had structured 4000 streets and alleys, as well as establishing appropriate specifications of roads, which are described in detail by Al-Munayes, (2015) in his book. The road should be free from any harmful elements, and muhtasib is responsible for preserving its good condition. Any building must be demolished if it transgresses into the area of a particular street, even it is a mosque.

The manual also emphasizes on the cleaning of streets in the market area; repairing damaged road due to sand or stagnant water; vehicles are not allowed to be maneuvered inside the markets; while fish and newly dyed clothes are regulated not be sold nearby the public access of the markets to prevent any harm, as elimination of harm is among the vital principle in urban management.Each design of the building must follow the guidelines set by muhtasib and approved by him; otherwise, he is allowed to demolish any premises that do not meet the standards. Among the designed guidelines are; hammam must consist of elevated temperature rooms; firewood should not be located nearby the oven; the furnaces cannot be located nearby public passages; non-Muslim's buildings cannot be built higher than Muslim's buildings; Muslim's buildings should not have any hole or small windows that enable the insiders to observe his neighbors or any outsiders; the doors and windows of the grain warehouse should be facing the east; while, the oil warehouse should be facing the west in order to preserve temperature, humidity, and lighting for the maintenance of the quality of goods.Ibn Abdun, (d. early 12th $A D$ ) also highlights muhtasib's concern over the standard of building tools and materials and ensures employees are always using the equipment as required. He also hung up the modeling molds on the wall of Friday mosques for inspection, instructs the processing of brick to be nearby wells, and prohibits using a wet mold.

The manual also concerns on building's maintenance, such as directing the appointment of an expert to preserve public infrastructures, also, oversee any damages on private buildings such as slanting walls that need to be demolished on the owner's expense.

\subsection{Utility management}

The management of waste disposal is highlighted repeatedly in most manuals. The waste should not be disposed of inside the city but on the outskirts. Shops or businesses that produce a lot of debris are obliged to do daily cleaning. Any refusal will deny the business operation in the market. In sewage management, Al-Saqati, (d. 12th AD) specifies that sewage containers cannot be cleaned inside the city. Each small container must be transferred and accumulated in a large box and transported by two men with bells on their hands as a warning for people to be cautious. He also prohibits a man from carrying two containers with both hands to prevent spilling and cause an unpleasant smell and impression among the people. Therefore, one large container should be carried by two persons, which reflects the concern on overburdening employees. Muhtasib regulates water management by building a pier to ease the extraction of water from the river, building a reservoir, or cistern nearby mosques as the center of water resources and specifying the allowed level of water in the process of river closure. Muhtasib also encourages people to build a new stream or to dig wells by granting land rights around the well.Muhtasib also concerns about the management of energy resources. He is responsible for maintaining the supply of coal since it is 
necessitated for food processing and warming the house during winter. Moreover, the defense of a city will be weakening without sufficient coals and will effortlessly fall into the hands of enemies as pressure causes them to burn any existing wood, including their own home, in order to survive.

\subsection{Maintenance of law and order in cities}

Muhtasib plays a crucial role in city law and order (Muhamad, 2017). To maintain ethical business transactions, Abdullah, (2000) highlights the function of Muhtasib in scale calibration and validation through Dar al-lyar (a center that produces measuring instruments and scales). Apart from being held accountable in the pricing policy by detecting price anomalies and adjusting the selling price, (Stilt, 2012) also addressed how muhtasib solved counterfeit money issues in Mamluk times.

In order to protect the well-being of the public, muhtasib is also responsible for ensuring that the local supply of goods is sufficient and always in good condition by monitoring the number of products in the warehouses, ensuring adequate staff in the dockyards to govern import and export activities and oversee the loading of goods to ensure vessels are not overloaded.

The muhtasib regulates the market size according to the current population to avoid issues concerning supply and demand, and employment. $\mathrm{He}$ is also responsible for bringing in trade and manufacturing specialists when needed. Muhtasib also is charged to monitor the daily working hours of employees, which starts from sunrise until sunset, or between 'asr and maghrib.

\subsection{Maintenance of Public Services}

Muhtasib highly concerns with public health, as he regulates rules on the production of food, medicine, and medical ethics. The enforced regulations in that matter include prohibiting unqualified doctors from practicing, sick people from working in food and medicine related industries. III people also prohibited from drawing water at water resources, yet, muhtasib directs others to help them.

The manual instructs the muhtasib to regulate the education system by preventing unauthorized persons from teaching and monitor appropriate syllabuses. Muhtasib should bring in experts, if necessary, to systematically improve the quality of education. Besides, muhtasib is responsible for building zawiya (Muslim religious community place), madrasa (schools), and makhazin (libraries). The muhtasib is also in charge of managing the salary of the educational institutions' staff, including the scholarships for students. During those times, access to education was opened for the public and not exclusive for certain people.

The manual also sets out some specific rules for protecting the welfare of women, such as; assigning trusted merchants to deal with women, allocating particular areas for women in the market.

In order to ensure customer satisfaction, the manuals prohibit barbers in the hammam from eating garlic before shaving his customers to not bothering them with his bad breath. The muhtasib must ensure the tailors and dryers of garments to put a tag of customers' names on their belongings so as not to get them mixed up and avoid procrastinating that will delay the delivery of the clothes.

In regard of safety matter, the manuals direct the muhtasib to immediately restore and repair city walls in the event of damage, set quality standards for the design of the building and the materials, and outline laws to prevent any kind of harm to the city, community, individual and the environment. Lange, (2009) recorded commentary of Sanai' (d. $1131 \mathrm{AD})$ who praises Muhtasib for offering a degree of security in times when the city is threatened with thieves, and the street is crowded with peasants. Thus, it indicates that muhtasib is also responsible for resolving the issue of robbery and any threats to the neighborhood. However, Stilt, (2012) suggests that cases such as theft are out of muhtasib's jurisdiction, and his interference was made voluntarily. Besides, some documents record the overlapping jurisdiction between Hisba and police institutions (Abdullah, 2000).Besides, muhtasib is also responsible for supervising the moral conduct of the citizens, including preventing the intermingling between men and women, prohibiting wine and prostitution, and inhibiting any acts which disturb public serenity.

\subsection{Conclusion}

In short, urban management, whether modern or traditional, aims at resolving urbanization issues and problems to preserve the wellbeing of the citizens. To this end, authorities constantly engaged appropriate ideas and methods to represent the public continuously. Interestingly, the active function in urban management is also prevalent in the institution of Hisba in Islamic civilization. Based on the analysis of Hisba manuals, the medieval Islamic society had successfully implemented six dimensions of urban management; urban planning, conservation of environment and biodiversity, utility management, maintenance of law and order, as well as maintenance of public services. Each dimension intricately illustrated muhtasib's job description in urban management, which also indicates a broad range of muhtasib's duties, not only as a market inspector. These aspects and approaches to urban management are, after all, worth exemplifying in developing cities by modern Muslim leaders.

\section{Acknowledgements}

The authors highly appreciate the funding and support from the Malaysian Ministry of Education and Institute of Research Management \& Innovation (IRMI) of University Teknologi MARA (UiTM). This research is funded by the Fundamental Research Grant Scheme (FRGS) grant no. 600-IRMI/FRGS 5/3 (202/2019). 


\section{References}

Abbasi, A. S., Rehman, K. U., \& Abbasi, S. H. (2010). Welfare and protection model for organizational management : The Islamic perspective. 4(May), 739-747.

Abdilla bin Khairol, N. binti A. B. (2013). Konsep Pembandaran Islam. 1-14.

Abdullah, A. bin H. (2000). Hisbah dan Pentadbiran Negara. IKDAS.

Al-Andalusi, Y. ibn U. (1975). Ahkam al-Suq. Al-Sharikah Al-Tunisiyyah Li Al-Tawzi.

Al-Dibaie, A. al-R. bin A. al-S. I. (2002). Bughyatul Irbah.pdf. University of Umm Qura

Al-Ishbili, M. ibn A. ibn 'Abdun. (1955). Risala fi al-Qada wa al-Hisba. In Tsalas Rasail Andalusia fi Adab al-Hisba wa al-Muhtasib. Maahad al-Ilmi al-Faransi li al-Atsar alSyarqiya.

Al-Jarsifi, U. (1973). Risalah fi al-Hisba. Cairo: Musthafa Bab Al-Halabi.

Al-Mawardi, A. I. M. (2014). Al-Ahkam al-Sultaniyah wa-al-Wilayat al-Diniyah. Al-Hakawati.

Al-Munayes, W. A. A. A. (2015). Al-Hisba Ala Al Mudun wa al-Umran. Wizara al-Awqaf wa al-Syuun al-Islamiah.

Al-Rauf, I. A. (1955). Risala fi Adab al-Hisba. In Tsalas Rasail Andalusia fi Adab al-Hisba wa al-Muhtasib. Maahad al-Ilmi al-Faransi li al-Atsar al-Syarqiya.

Al-Saqati, M. bin A. M. (1931). Adab al-Hisba wa al-Muhtasib.

Al-Shayzari, A. R. ibn N. (2003). Nihayat al-Rutba fi Talah al-Hisba. Dar al-Kutub al-IImiyah.

BAČLIJA, I. (2013). RECONCEPTUALISATION OF URBAN MANAGEMENT: EVIDENCE FROM EU CITIES. Theoretical \& Empirical Researches in Urban Management, $8(1)$.

Bhadur, S. (2017). Urban Management and Management Of Urban Services. IGNOU.

Buckley, R. P. (2000). The Book of the Islamic Market Inspector.

Ibn al-Rami. (1999). Al-i c lān bi ahkām al-bùnyān. Ben Slimane Férid (éd.), Centre de publication universitaire, Tunis.

Jaafar al-Dimasyqi. (1999). al-Isyarah ila Mahasin al-Tijarah. Dar Sadir.

Lagiman, N. bin. (2015). Indikator kesejahteraan perancangan bandar islam. Universiti Teknologi Malaysia.

Lange, C. (2009). Changes in the office of Hisba under the Seljuqs. 39(1992).

Manzano, E. (2015). Why did Islamic Medieval Institutions Become so Different from Western Medieval Institutions? Medieval Worlds, 2(2412), 118-137. https://doi.org/10.1553/medievalworlds

Moukheiber, K. (2019). Beyond Halāl: The Dos and Don'ts of Syrian Medieval Cookery in a Twelfth-Century Market Inspector Manual. In Insatiable Appetite: Food as Cultural Signifier in the Middle East and Beyond (pp. 84-99). Brill.

Muhamad, M. D. (2017). Islamic building regulations: the fourteenth-century Tunis book and its counterparts. In Building Regulations and Urban Form, 1200-1900 (pp. 23-37). Routledge.

Muhamad, M. D. (2018). Shariah and Built Environment. Casis, Universiti Teknologi Malaysia.

Musa, M. J. A. al-H. (2016). Tarikh al-Hisba wa al-Muhtasibin bi Misr fi al-Asr al-Mamluki. Dar al-Afaq al-Arabiyah.

Rutledge, K., McDaniel, M., Boudreau, D., Ramroop, T., Teng, S., Sprout, E., Costa, H., Hall, H., \& Hunt, J. (2011). Urban area. In National Geographic. https://www.nationalgeographic.org/encyclopedia/urban-area/

Saad, S., \& Radzi, M. M. (2015). Urus tadbir sebuah bandaraya Islam Malaysia : Kajian kes di Kota Bharu , Kelantan. 3(3), 8-25.

Sabri Orman, A. S. (2017). Market Supervisor / Inspector " and "Public Moral Officer " as Translation of the Term Muhtasib : An Evaluation of Their Appropriateness " Market Supervisor / Inspector" and "Public Moral Officer" as Translations of the Term Mu I tasib : An Evaluation. May.

Saliba, G. (1994). A History of Arabic Astronomy

Saraçoğlu, M. S. (2015). Economic Interventionism, Islamic Law and Provincial Government in the Ottoman Empire. Journal of the Ottoman and Turkish Studies Association, 2(1), 59-84.

Selangorkini.my. (2013, October 23). Elemen Islam jadi elemen pembangunan Pusat Bandar Shah Alam. Selangorkini, 1-6. https://selangorkini.my/2013/10/elemenislam-jadi-elemen-pembangunan-pusat-bandar-shah-alam/

Stilt, K. (2012). Islamic law in action: Authority, discretion, and everyday experiences in Mamluk Egypt. OUP Oxford.

Syarqawi, A. K. (2018). Qada' al-Hisba wa Hishanat al-Adyan fi Fiqh al-Islami wa al-Qanun al-Wadh'i: Dirasat Muqaranah (p. 143). Maktaba al-Wafa' al-Qanuniya. 